\title{
Respon Bibit Tebu Akibat Komposisi Media Tanam yang Diaplikasikan Formulasi Dobel Inokulan Pseudomonad Pendarflor dan Azospirillum.
}

\author{
(Response of Sugarcane Seedling Due to Growth Medium Composition of Applied Double Inoculant Formulation of \\ Fluorescent Pseudomonads and Azospirillum)
}

Gita Pawana*, Achmad Djunaedy, dan Syaiful Khoiri

Program Studi Agroekoteknologi, Fakultas Pertanian, Universitas Trunojoyo Madura

Jl. Raya Telang PO BOX 2 Kamal, Bangkalan, Jawa Timur, Indonesia

*Email korespondensi: gitapawana@trunojoyo.ac.id

Diterima 13 Mei 2019/Disetujui 21 Mei 2019

\begin{abstract}
To get good quality seedlings tolerant of biotic and abiotic stresses with good rooting and fertilization efficient on growth medium were applied the double iniculant formulation of fluorescent pseudomonad and Azospirillum, however in sugarcane nurseries information about this was still limited. The purpose of this study was to determine the effect of the composition of the growth medium were applied the double inoculant formulation of fluorescent pseudomonad and Azospirillum to the growth of sugarcane budchip seedlings. Budchip is planted on nursery trays with the composition of the growth medium as treatment, that is M1: top soil and organic matter with a composition of 1: 1, M2: top soil and double inoculant formulation of fluorescent pseudomonad and Azospirillum with composition of 1: 1, M3: top soil and double

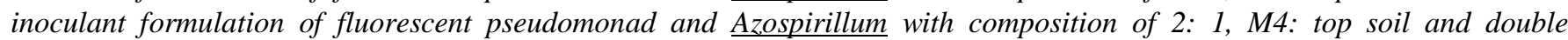

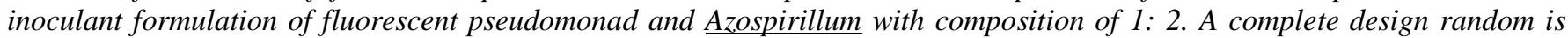
used. On data parameters were analyzed by analiysis of variance, if there were significant differences followed by Duncant multiple distance test with $\alpha=5 \%$. The parameters of the data observed included: plant height, stem diameter, number of leaves, living seeds, number of primary and secondary roots, and plant biomass. The conclusion obtained is that the double inoculant formulation of fluorescent pseudomonad and Azospirilum can increase the growth of sugarcane seedlings, can stimulate secondary root growth. The growth medium with the composition of top soil and doble inoculant formulation of fluorescent pseudomonad and Azospirillum with composition of $1: 1$ is the most ideal composition.
\end{abstract}

Keywords: Azospirillum, Fluoerescent pseudomonad, growth, sugarcane seedling.

\section{ABSTRAK}

Untuk mendapatkan bibit berkualitas baik toleran terhadap cekaman biotik dan abiotik dengan perakaran baik dan efisien terhadap pemupukan pada media tanam diaplikasikan formulasi dobel inokulan pseudomonad pendarflor dan Azospirillum, namun demikian pada pembibitan tebu informasi tentang hal ini masih terbatas. Tujuan penelitian ini adalah untuk mengetahui pengaruh komposisi media tanam yang diaplikasikan formulasi dobel inokulan pseudomonad pendarflor dan Azospirillum terhadap pertumbuhan bibit budchip tebu. Budchip ditumbuhkan pada nampan pembibitan dengan komposisi media tanam sebagai perlakuan yaitu M1: top soil dan bahan organik dengan komposisi 1:1, M2: top soil dan formulasi dobel inokulan pseudomonad pendarflor dan Azospirillum dengan komposisi 1:1, M3: top soil dan formulasi dobel inokulan pseudomonad pendarflor dan Azospirillum dengan komposisi 2:1, M4: top soil dan formulasi dobel inokulan pseudomonad pendarflor dan Azospirillum dengan komposisi 1:2. Digunakan rancangan acak lengkap. Pada parameter data dilakukan analisa varian, jika terdapat perbedaan yang siknifikan dilanjutkan dengan uji jarak berganda Duncan dengan $\alpha=5 \%$. Parameter data yang diamati meliputi: tinggi tanaman, diameter batang, jumlah daun, bibit yang hidup, jumlah akar primer dan sekunder, dan biomassa tanaman. Kesimpulan yang diperoleh adalah formulasi konsursium pseudomonad pendarfluor dan Azospirilum dapat meningkatkan pertumbuhan pembibitan tebu, dapat menstimulasi pertumbuhan akar sekunder. Adapun media tanam dengan komposisi top soil dan formulasi dobel inokulan pseudomonad pendarflor dan Azospirillum 1:1 merupakan komposisi yang paling ideal.

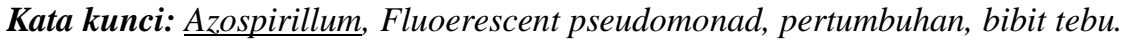




\section{PENDAHULUAN}

Penggunaan bibit tanaman dengan kondisi yang bagus merupakan awal dari aktifitas produksi tanaman yang dipenuhi dalam good agricultur practise. Seleksi bibit mutlak harus dilakukan sehingga bibit yang dipindahkan ke lahan akan berada pada kondisi sehat bebas hama penyakit serta mempunyai vigoritas yang tinggi, hal ini tidak lepas dari proses produksi bibit yang dilakukan. Untuk memberikan nilai tambah pada bibit sehingga setelah transplanting bibit menjadi tanaman lebih toleran terhadap cekaman lingkungan abiotik ataupun biotik dapat dilakukan dengan menginokulasikan bibit dengan rhizobakteri pemacu pertumbuhan tanaman. Lebih jauh jika bibit tersebut di pindahkan ke lahan, maka penambahan pupuk sisntetik fosfat dan nitrogen dapat dikurangi, demikian juga dengan pemakaian pestida juga akan menurun karena rhizobakteri pemacu pertumbuhan tanaman yang diamendasikan bersifat antagonis terhadap patogen tular tanah serta dapat meninduksi ketahanan sistemik, yang pada akhirnya biaya input untuk budidaya dapat dikurangi.

Dijelaskan oleh Glick (2012) bahwa pseudomonad pendarflur dan Azospirillum merupakan rhizobakteri pemacu pertumbuhan tanaman, hal ini dikarenakan pseudomonad pendarflur dapat meningkatkan ketersediaan fosfat, menghasilkan fitohormon (indole acetic acid / IAA), antagonis terhadap patogen tular tanah, menginduksi ketahanan sistemik serta meningkatkan toleransi tanaman terhadap cekaman kekeringan dan tingkat kadar garam. Adapun Azospirillum bukan meningkatkan ketersediaan fosfat dan antagonis terhadap patogen tular tanah melainkan meningkatkan ketersedian nitrat atau amonium.

Pawana et al. (2012) menemukan bahwa isolat pseudomonad pendarflur indigenus Madura yang diaplikasikan pada rhizosfer tembakau dapat mengurangi tingkat serangan penyakit batang berlubang dan meningkatkan serapan fosfat pada tanaman tembakau. Peningkatan serapan fosfat tersebut menunjukkan bahwa pseudomonad pendarfluor meningkatkan ketersediaan fosfat pada rhizosfer, walaupun secara in vitro ketersediaan fosfat tersebut tidak bersifat akumulatif (naik turun) seiring dengan bertambahnya waktu inkubasi (Pawana et al., 2013). Selain itu Saber et al. (2015) menemukan bahwa aplikasi pseudomonad pendarfluor yang berkemampuan penghasil IAA, cianida bersifat antagonis terhadap patogen tular tanah, pelarut fosfat dan kalium pada pembibitan tomat memberikan pengaruh pada penekanan serangan patogen tular tanah, meningkatkan serapan NPK serta mensuport pertumbuhan tanaman.

Ditemukan oleh Ashraf et al. (2011) bahwa selain mengfiksasi nitrogen Azosspirillum yang diisolasi dari rhizosfer tebu saat diinokulasikan pada sorghum juga dapat meningkatkan panjang akar dan berat kering tanaman. Adapun Prasad dan Babu (2017) menemukan bahwa inokulasi secara ganda Azospirillum brasilense dan Pseudomonas fluorescens pada kacang tanah bersifat kompatibel dan memberikan pertumbuhan yang lebih baik dari pada diinokulasikan secara tunggal Azospirillum brasilense atau Pseudomonas fluorescens saja. Adapun
Aponte et al. (2017) nemukan bahwa secara in vitro konsursium Pseudomonas fluorescens dan Azospirillum sp.tidak memberikan pengaruh pada perkecambahan benih selada, namun secara in vivo kosursium tersebut menunjukkan bekerja secara sinergis meningkatkan luas daun dan berat kering tanaman dan mampu memicu mekanisme toleransi terhadap cekaman cekaman abiotik seperti tingkat temperatur dan salinitas. Selain itu juga dinyatakan oleh Puttaradder dan Lakshman (2017) bahwa inokulasi secara triple antara cendawan mikoriza, Azospirillum brasilense dan Pseudomonas fluorescens telah menunjukkan pertumbuhan lebih baik dari pada inokulasi tunggal ataupun ganda pada pertumbuhan tanaman Capsicum anпиum L. Penelitian ini bertujuan mengkaji bagimanakah pengaruh komposisi media tanam yang diaplikasikan formulasi dobel inokulan pseudomonad pendarfluor dan Azospirillum terhadap pertumbuhan bibit tebu yang menggunakan budchip.

\section{BAHAN DAN METODE}

\section{Bahan}

Budchip yang digunakan berasal dari mata tunas tebu varietas Bululawang yang diambil dari tanaman yang telah berumur 7 bulan pada ruas ke tiga dan ke empat dari pucuk tanaman. Isolat pseudomonad pendarfluor dan azospirillum merupakan isolat koleksi dari laboratorium lingkungan program studi Agroekoteknologi Universitas Trunojoyo Madura, yang dipelihara pada agar miring dan disimpan dalam lemari pendingin. Formulator (bahan organik) yang digunakan berasal dari limbah (debu) pupuk Petroganik yang diambil dari pabrik yang terdapat di Kec Burneh Kab. Bangkalan. Topsoil yang digunakan diambil dari lahan/kebun penelitian program studi Agroekoteknologi Universitas Trunojoyo Madura sampai dengan kedamalan 10 $\mathrm{cm}$ dari atas permukaan tanah.

\section{Pembuatan formulasi dobel inokulan pseudomonad pendarfluor dan Azospirillum}

Isolat pseudomonad pendarfluor dan Azospirillum dikulturkan pada media agar miring kemudian diinkubasikan pada temperatur ruang selama 24 jam. Setelah diinkubasikan kultur isolat disuspensikan dengan air steril dengan menghomogenkan pada fortex sampai semua koloni yang ada tersuspensi. Kemudian pada suspensi yang diperoleh ditentukan kerapatan selnya berdasarkan metode turbidimeter dengan menggunakan spectrofotometer. Kerapatan sel ditentukan dengan mengencerkannya pada air steril sampai diperoleh kerapatan sel $10^{8}$. Formulasi inokulan dibuat dengan cara mencampurkan setiap $10 \mathrm{~g}$ bahan organik dengan dengan $10 \mathrm{ml}$ suspensi isolat pseudomonad pendarfluor dan Azospirillum. Selanjutnya formulasi inokulan dikering anginkan sampai diperoleh kadar air $15 \%$. 


\section{Pembibitan/persemaian budchip}

Budchip disemaiaakan pada nampan persemaian dengan dengan komposisi media tanam digunakan sebagai perlakuan yang meliputi M1, M2, M3 dan M4 yaitu:

M1: topsoil dan bahan organik dengan komposisi 1:1

M2: topsoil dan formulasi dobel inokulan pseudomonad pendarfluor dan Azospirillum dengan komposisi $1: 1$

M3: topsoil dan formulasi dobel inokulan pseudomonad pendarfluor dan Azospirillum dengan komposisi $2: 1$

M4: topsoil dan formulasi dobel inokulan pseudomonad pendarfluor dan Azospirillum dengan komposisi dengan komposisi 1:2

Pemotongan mata tunas tebu/ budchip dalam bentuk setengah lingkaran, kemudian dilakukan desinfeksi selama 30 menit dengan menggunakan fungisida berbahan aktif propineb $70 \%$ pada konsentrasi $2 \mathrm{~g}$ dalam 1 liter air. Selanjutnya budchip langsung disemaikan ke dalam nampan persemaian dengan posisi mata tunas menghadap ke atas. Nampan persemaian diletakkan di bawah paranet dengan intensitas sinar masuk $70 \%$. Kemudian dipelihara sampai berumur 40 hari setelah semai. Pemeliharaan meliputi penyiraman dan pengendalian organisme pengganggu tanaman.

\section{Parameter Pertumbuhan}

Parameter pertumbuhan yang diamati adalah a) tinggi tanaman, b) diameter batang, c) jumlah daun, d) jumlah budchip yang berhasil menjadi bibit, e) jumlah akar primer dan sekunder, f) biomassa tanaman.

Tinggi tanaman diukur dari pangkal batang sampai pucuk daun terpanjang, diameter batang diukur pada pangkal bantang dengan menggunakan jangka sorong, jumlah daun dihitung pada daun yang telah membuka sempurna. Periode pengamtan dilakukan setiap satu minggu sekali sampai 5 minggu setelah semai. Jumlah akar primer dihitung pada akar yang tumbuh pada batang bibit (tidak termasuk akar yang tumbuh dari budchip), jumlah akar sekunder dihitung pada akar lateral yang tumbuh pada akar primer terpanjang. Jumlah akar primer, akar sekunder dan bimassa tanaman diamati pada saat umur 5 minggu setelah semai.

\section{Rancangan percobaan dan analisa data}

Digunakan rancangan acak lengkap dengan faktor tunggal komposisi media tanam, selanjutnya untuk mengetahui perbedaan antar perlakuan pada data parameter yang diperoleh dilakukan analisa varian dengan $\alpha: 5 \%$ dan jika terdapat perbedaan yang signifikan dilanjutkan pada uji jarak berganda Duncan.

\section{HASIL DAN PEMBAHASAN}

\section{Hasil}

Tinggi tanaman dipengaruhi oleh komposisi media tanam. Perlakuan M3 berbeda dan lebih tinggi dari pada perlakuan lainnya. Adapun M1 dan M2 cenderung sama dan M4 berbeda dan lebih rendah dari pada perlakuan lainnya. Perkembangan tinggi tanaman selengkapnya disajikan pada Gambar 1.

Jumlah daun dipengaruhi oleh komposisi media tanam, hal ini ditunjukkan dengan jumlah daun pada perlakuan MI, M2 dan M3 cenderung sama, namun lebih banyak dan berbeda nyata dengan M4. Hasil pengamatan perkembangan jumlah daun selengkapnya disajikan pada Gambar 2.

Diameter batang dipengaruhi komposisi media tanam setelah minggu ke tiga. Diameter batang pada perlakuan M1 paling besar diantara perlakuan lainnya namun cenderung sama dengan perlakuan M2 dan M3. Hasil pengamatan perkembangan diameter batang selengkapnya disajikan pada Gambar 3.

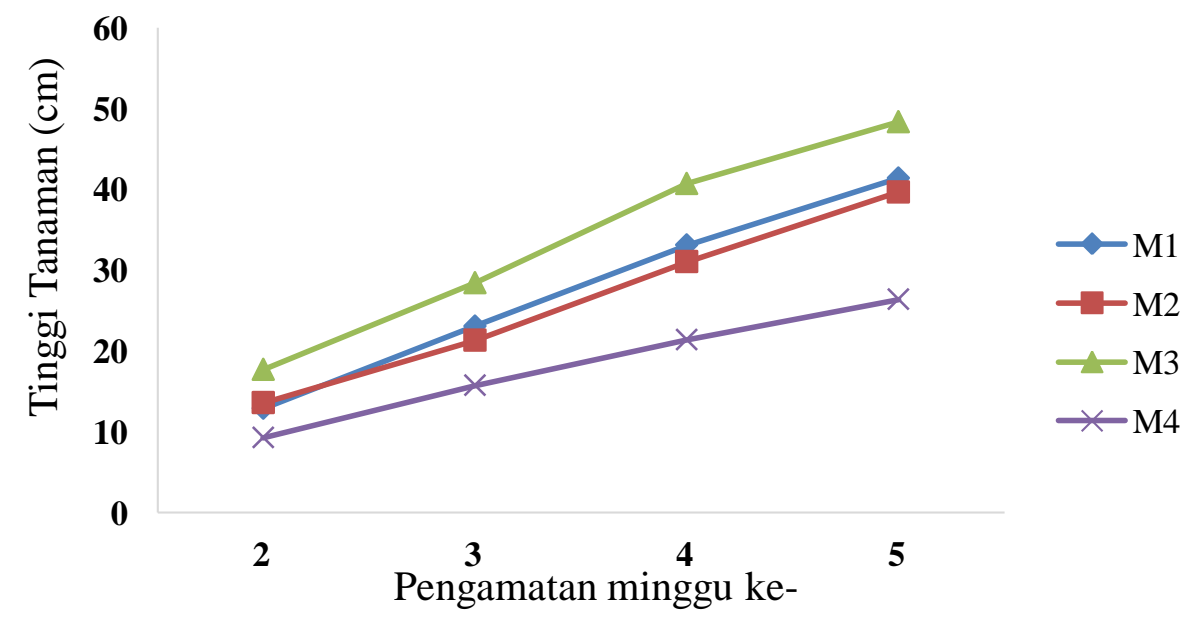

Gambar 1. Perkembangan Tinggi Tanaman Pada Berbagai Perlakuan 


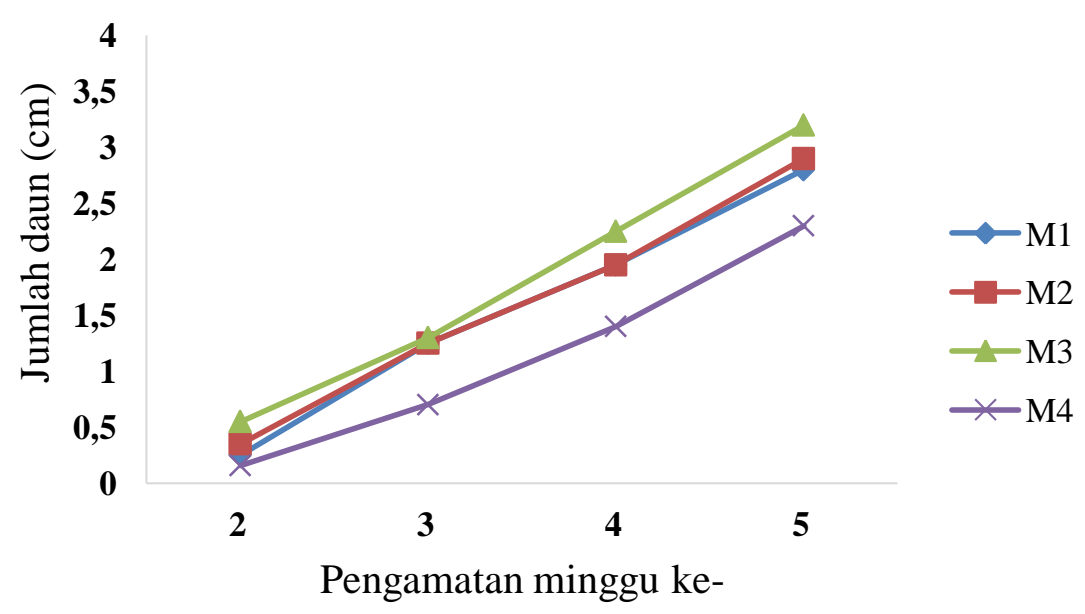

Gambar 2. Perkembangan Jumlah Daun Pada Berbagai Perlakuan

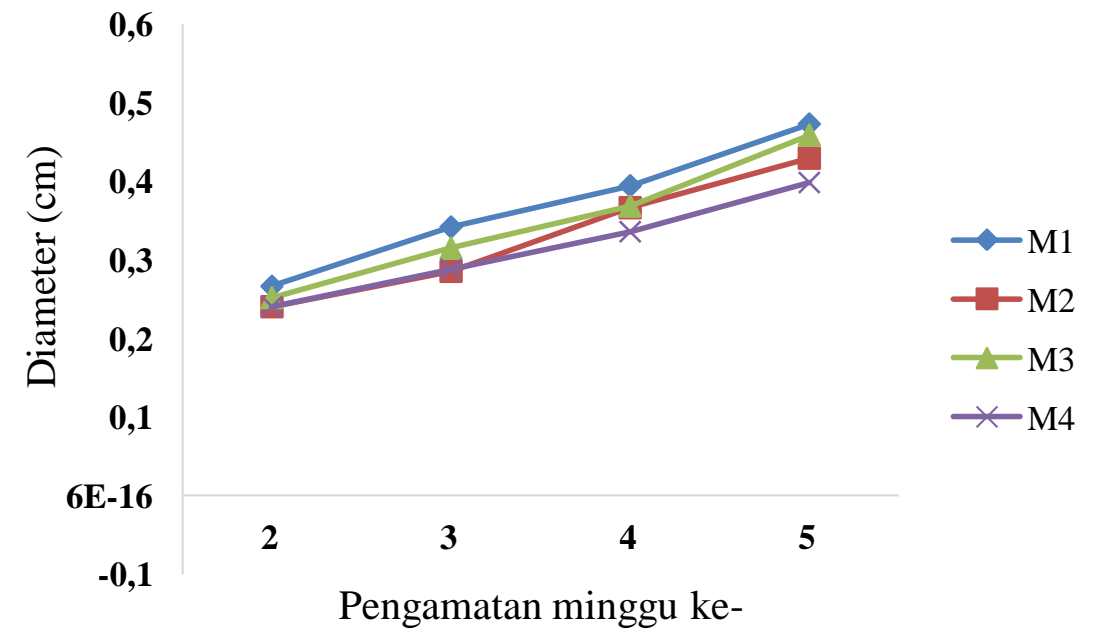

Gambar 3. Perkembangan Diameter Batang Pada Berbagai Perlakuan

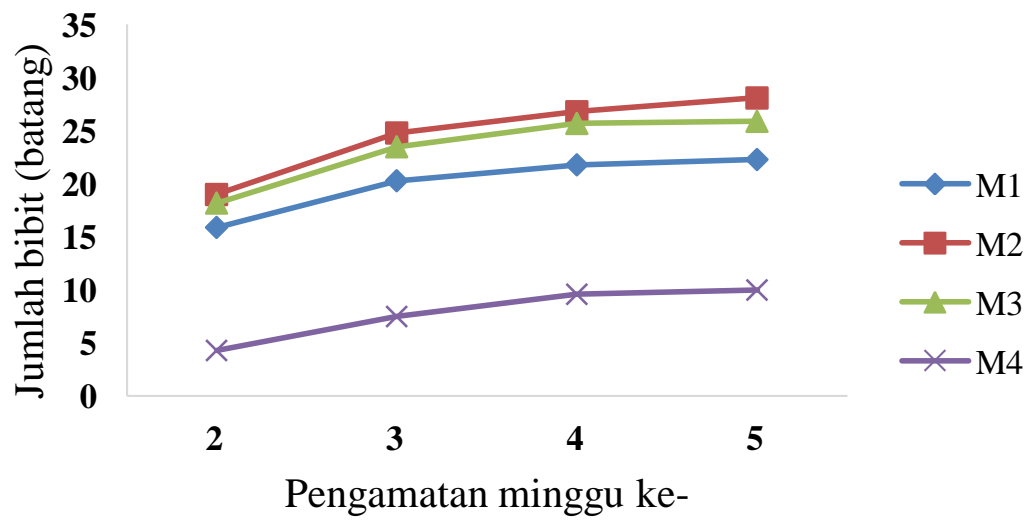

Gambar 4. Perkembangan Jumlah Budchip yang Berhasil Menjadi Bibit 


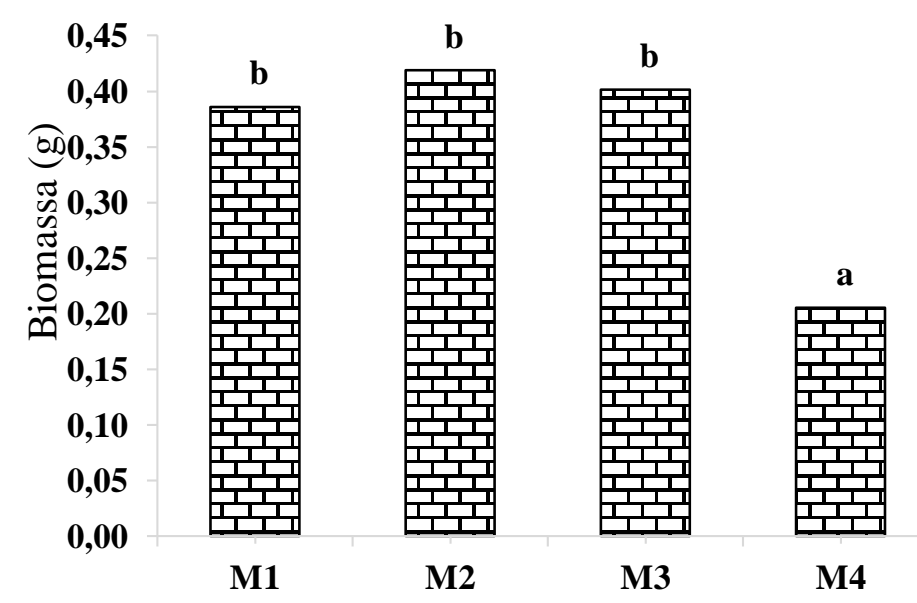

Gambar 5. Pengaruh komposisi media tanama terhadap biomassa tanaman

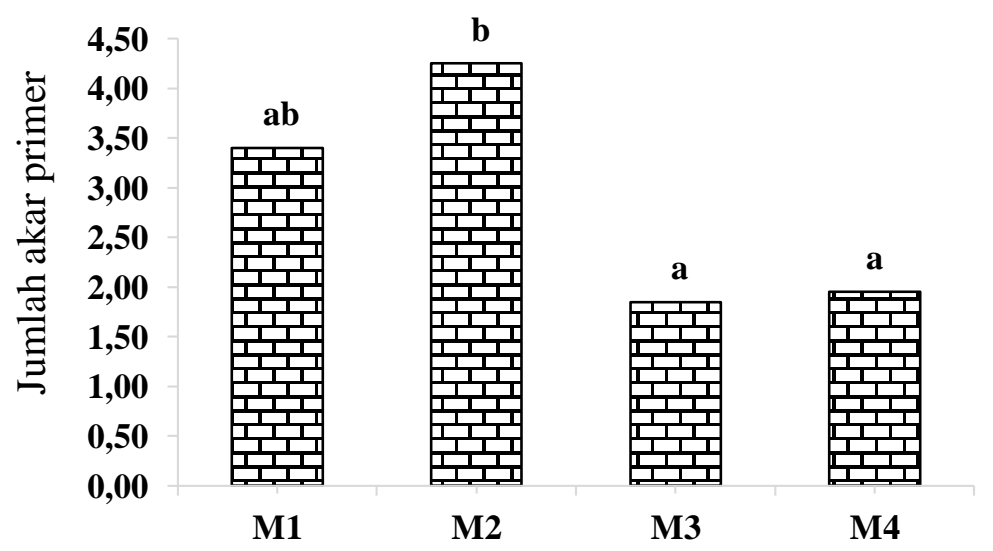

Gambar 6. Pengaruh komposisi media tanaman terhadap jumlah akar primer

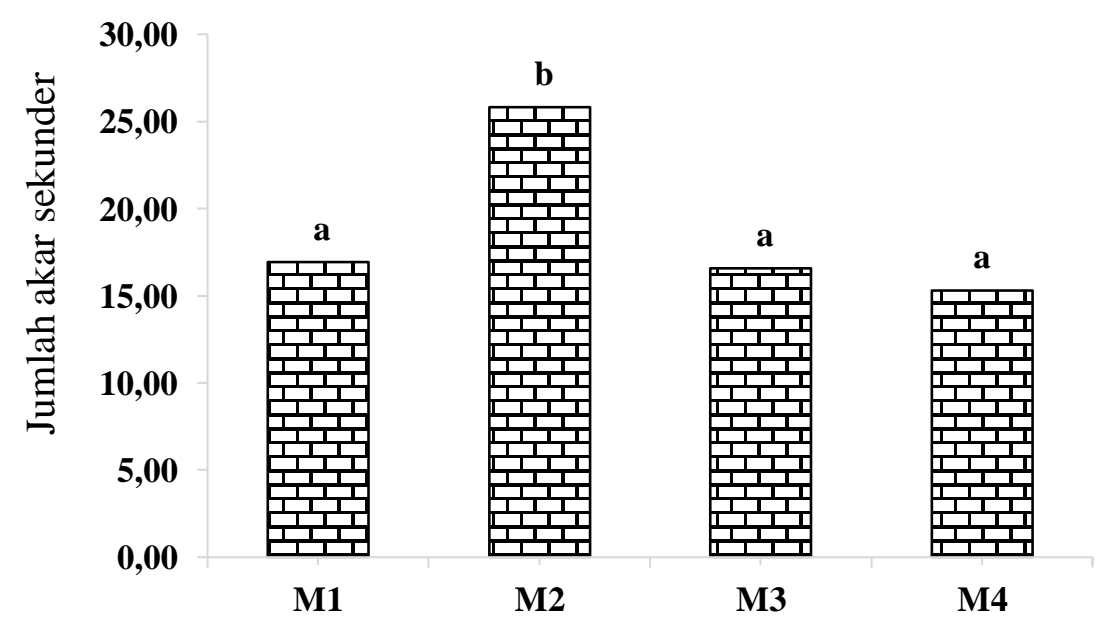

Gambar 7. Pengaruh perlakuan media tanama terhadap jumlah akar sekunder 


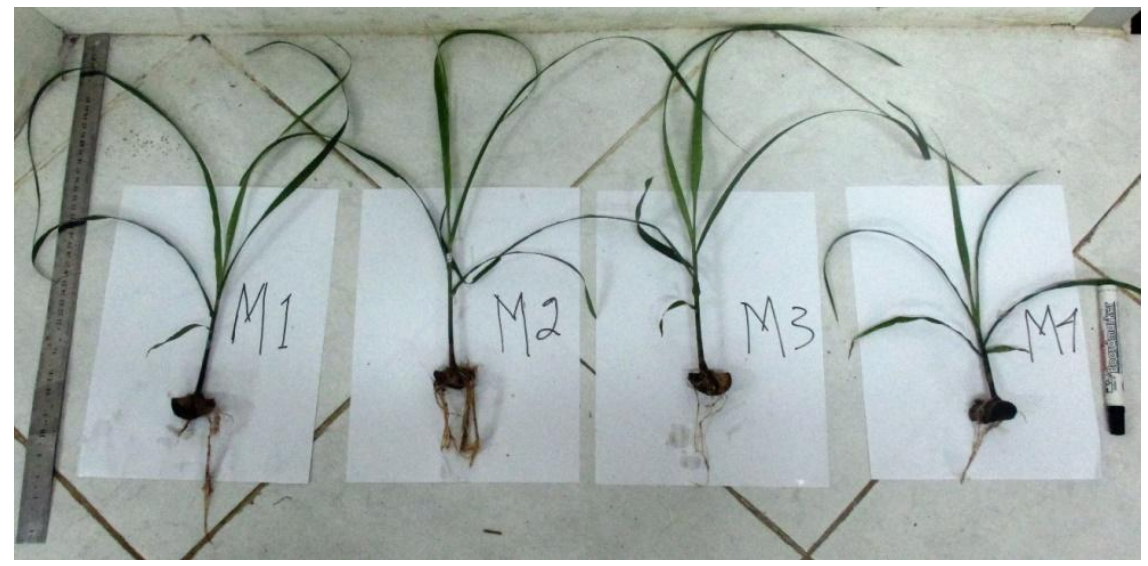

Gambar 8. Keragaan bibit tebu 5 minggu setelah semai pada berbagai komposisi media tanam

Jumlah budchip yang berhasil menjadi bibit pada semua periode pengamatan dipengaruhi komposisi media tanam. Budchip yang berhasil menjadi bibit pada perlakuan M1, M2 dan M3 cenderung sama, namun berbeda nyata dengan perlakuan M4. Hasil pengamatan perkembangan jumlah budchip yang berhasil menjadi bibit disajikan pada Gambar 4. Biomassa tanaman dipengaruhi komposisi media tanam. Perlakuan M1, M2 dan M3 cenderung sama, namun lebih tinggi berbeda nyata dengan M4. Hasil pengamatan biomassa tanaman disajikan pada Gambar 5.

Jumlah akar primer dipengaruhi komposisi media tanam, perlakuan M2 memberikan pengaruh teringgi dari pada perlakuan lainnya namun cenderung sama dengan perlakuan M1. Perlakuan M1 dan M3 berbeda dengan M4 cenderung sama. Hasil pengamatan jumlah akar primer disajikan pada Gambar 6.

Jumlah akar sekunder dipengaruhi oleh komposisi media tanam. Perlakuan M1, M3 dan M4 cenderung sama, namun berbeda nyata dengan M2, dan perlakuan M2 memberikan pengaruh yang paling tinggi dan berbeda nyata denngan perlakuan lainnya. Hasil pengamatan jumlah akar sekunder disajikan pada Gambar 7.

Karakteristik pertumbuhan budchip menjadi bibit tebu dimulai dengan pertumbuhan primordia-primordia akar yang terdapat pada budchip menjadi akar primer, kemudian diikuti dengan pecahnya mata tunas yang selanjutnya diikuti dengan keluaranya batang dan daun. Kondisi ini menunjukkan bahwa untuk bisa tumbuh menjadi bibit tebu budchip memerlukan hara (energi) yang diperoleh dari media tanam, tidak cukup dengan energi yang tersimpan dalam budchip.

Komposisi media tanam atau perbandingan antara top soil dan formulasi dobel inokulan pseudomonad pendarfluor dan Azospirillum pada perlakuan M4 adalah 1:2, sehingga volume top soil yang ada 2 kali lebih rendah dari pada perlakuan lainnya, namun jumlah mikroba (pseudomonad pendarfluor dan Azospirillum) 2 kali lebih tinggi dari pada perlakuan lainnya. Kondisi ini mengakibatkan kandungan hara pada media tanam perlakuan M4 lebih rendah dari pada perlakuaan lainnya. Kondisi kandungan hara yang lebih rendah ini mengakibatkan tinggi tanaman pada perlakuan M4 lebih rendah dan dan jumlah daun pada perlakuan M4 lebih sedikit dari pada perlakuan lainnya. Adapun tinggi tanaman dan jumlah daun pada perlakuan M3 cenderung lebih tinggi dan lebih banyak dari pada perlakuan M1 dan M2. Hal ini menunjukkan bahwa kebutuhan hara bagi bibit tebu yang berasal dari budchip sampai dengan lima minggu setelah semai masih cukup disediakan oleh media tanam kecuali pada perlakuan M4. Disisi lain sampai dengan lima minggu setelah semai pseudomonad pendarfluor dan Azospirillum yang diinokulasikan telah menunjukkan peranannya dalam parameter tinggi tanaman, namun peran tersebut belum berkontribusi dalam pembentukan jumlah daun, hal ini kemungkinan akibat fosfat dan nitrogen yang disediakan oleh pseudomonad pendarfluor dan Azospirillum jumlahnya rendah sehingga tidak dapat memberikan kontribusi yang berarti bagi pembentukan jumlah daun, namun jumlah IAA yang dihasilkan telah dapat menstimuli pertumbuhan tanaman dalam hal ini meningkatkan tinggi tanaman.

Seperti dijelaskan oleh Mardad et al. (2013) dan Zadeh et al. (2010) bahwasanya jumlah fosfat tersedia akibat aktifitas pseudomonad pendarfluor sangat ditentukan oleh jumlah fosfat terikat yang terdapat pada rhizosfer, juga jumlah fosfat yang digunakan sendiri oleh pseudomonad pendarfluor untuk aktifitas pertumbuhan dan perkembangannya, demikian juga dengan Azospirillum terlebih dahulu akan memanfaatkan nitrogen yang berhasil difiksasi olehnya untuk aktifitas pertumbuhan dan perkembangannya. Kemudian setelah Azospirillum mati maka nitrogen hasil fiksasi yang berbentuk protein akan diuraikan menjadi asam amino, amonium dan nitrat untuk dapat dimanfaatkan oleh tanaman.

Jumlah pseudomonad pendarfluor dan Azospirillum yang lebih banyak pada perlakuan M4, ternyata memberikan dampak terhadap jumlah budchip yang berhasil menjadi bibit tebu. Pada perlakuan M4 tampak jumlah budchip yang berhasil menjadi bibit tebu berbeda dan paling sedikit dari pada perlakuan lainnya. Adapun hal yang dapat dikemukakan terkait dengan hal ini adalah bawasanya diketahui pertumbuhan premordia akar yang selanjutnya diikuti dengan pecahnya mata tunas, merupakan fase yang sangat lemah dalam pertumbuhan bibit tebu, mempunyai sensitifitas yang cukup tinggi terhadap kondisi lingkungan. 
Sensitifitas yang cukup tinggi dalam menerima konsentrasi asam organik yang dieksudasikan oleh pseudomonad pendarfluor dan Azospirillum mengakibatkan tidak berkembangnya atau matinya premordia akar yang selanjutnya berdampak pada tidak dapat pecahnya mata tunas. Oleh karenanya pada perlakuan M4 ini jumlah budchip yang berhasil menjadi bibit tebu paling rendah dari pada perlakuan lainnya. Adapun pada perlakuan lainnya jumlah budchip yang berhasil menjadi bibit tebu cenderung sama, walaupun pada perlakuan M2 dan M3 cenderung keberhasilan budchip yang menjadi bibit tebu lebih banyak dari pada perlakuan M1. Kondisi ini menunjukkan bahwa adanya inokulan pseudomonad pendarfluor dan Azospirillum pada perlakuan M2 dan M3 memberikan dampak pada jumlah IAA yang lebih banyak, jumlah IAA yang lebih banyak ini tampak berperan dalam menstimulasi pemecahan mata tunas untuk membentuk daun batang sehingga memberikan keberhasilan yang lebih tinggi jumlah budchip yang berhasil menjadi bibit. Kondisi ini juga terkait erat dengan parameter tinggi tanaman pada perlakuan M2 dan M3 yang juga memberikan tinggi tanaman yang lebih tinggi dari perlakuaan lainnya yang dimungkinkan akibat dari IAA yang dihasilkan oleh inokulan pseudomonad pendarfluor dan Azospirillum.

Pada perlakuan M1, M2 dan M3 juga diperoleh ukuran diameter batang yang sama, hal ini sesuai dengan karakter bibit tebu yang masih muda bawasanya diameter batang sesungguhnya terbentuk dari lapisan-lapisan pelepah daun karena batang yang sesungguhnya belum terbentuk (terukur). Oleh karenanya jika pada perlakuan M1, M2 dan M3 diperoleh jumlah daun yang sama maka pada perlakuan tersebut juga akan diperoleh diameter batang yang sama pula. Namun demikian diameter batang terpanjang terdapat pada perlakuan M1 kemudian dikuti M2, hal ini menunjukkan bahwa sampai dengan 5 minggu setelah semai komposisi media tanam atau perbandingan antara top soil dan bahan organik tanpa diberikan inokulan pseudomonad pendarfluor dan Azospirillum media tanam yang lebih baik dari pada dengan diberikan inokulan. Sebagaimana yang disebutkan di atas tampaknya pengaruh asam-asam organik yang dieksudasikan oleh inokulan pseudomonad pendarfluor dan Azospirillum pada bahan organik formulatornya juga memberikan pengaruh terhadap pembentukan diameter batang.

Biomassa tanaman pada perlakuan M1, M2 dan M3 cenderung sama namun berbeda dan lebih tinggi dari perlakuan M4. Hal ini menunjukkan bahwa jumlah daun pada perlakuan M3 yang lebih banyak dari perlakuan M1 dan M2 tidak dapat memberikan kontribusi yang nyata dalam menghasilkan fotosintat, seperti diketahui bahwasanya biomassa merupakan perwujudan dari pertumbuhan dan perkembangan tanaman sebagai dampak dari aktifitas fotosintesis.

Di sisi lain jumlah akar primer yang tumbuh dari pangkal batang dan akar sekunder yang tumbuh sebagai percabangan akar primer pada perlakuam M1, M3 dan M4 cenderung sama. Namun demikian jumlah akar primer pada perlakuan M2 cenderung sama dengan perlakuan M1, adapun jumlah akar sekunder pada perlakuan M2 berbeda nyata dan lebih banyak dari pada perlakuan lain. Hal yang memungkinkan dapat menjelaskan kondisi ini adalah jumlah IAA yang dihasilkan oleh Pseudomonad pendarfluor dan Azospirillum lebih menstimulasi pembentukan akar sekunder dari pada akar primer. Hal ini seiring dengan jumlah budchip yang berhasil menjadi bibit dan serta tinggi tanaman pada perlakuan M2 lebih dominan dari pada perlakuan lain (Gambar 8).

\section{KESIMPULAN}

Kesimpulan yang diperoleh adalah formulasi dobel inokulan pseudomonad pendarfluor dan Azospirillum dapat meningkatkan jumlah budchip yang berhasil menjadi bibit tebu, pertumbuhan pembibitan tebu dan menstimulasi pertumbuhan akar sekunder. Adapun media tanam dengan komposisi top soil dan formulasi dobel inokulan pseudomonad pendarflor dan Azospirillum 1:1 merupakan komposisi yang paling ideal.

\section{UCAPAN TERIMA KASIH}

Kami ucapkan banyak terima kasih kepada pusat inovasi Universitas Trunojoyo Madura atas pendanaannya dalam penelitian ini, serta koordinator laboratorium lingkungan tanaman prodi Agroekoteknologi yang telah mempersilahkan atas penggunaan isolat pseudomonad pendarfluor dan Azospirillum dari koleksi laboratorium lingkungan tanaman.

\section{DAFTAR PUSTAKA}

Aponte, A., O. Castillo, G. Cabrera, M. Pernia, Y. Hernandez. 2017. Rhizobacteria Pseudomonas fluorescens and Azospirillum sp. association enhances growth of Lactuca sativa L. under tropical conditions. Journal of Central European Agriculture. 18(2): 424-440. DOI: 10.5513/JCEA01/18.2.1916

Ashraf, M.A., M. Rasool, M.S. Mirza. 2011.Nitrogen fixation and indole acetic acid production potential of bacteria isolated from rhizosphere of sugarcane (Saccharum officinarum L.). Advances in Biological Research 5 (6):348-355.

Glick, B.R. 2012. Review article. Plant growth-promoting bacteria: Mechanism and applications. Hindawi Publishing Corporation. Scientifica.Volume 2012, Article ID 963401, 15 pages. http://dx.doi.org/10.6064/2012/963401.

Mardad, I., A. Serrano, A. Soukri. 2013. Solubilization of inorganic phosphate and production of organic acids by bacteria isolated from a Moroccan mineral phosphate deposit. Afr. J. of Microbiol. Research 7(8):626-635. 
Pawana, G., Syekhfani, T. Surtiningsih, W.S. Wahyuni. 2012. Interaksi pseudomonad pendarfluor indegenus dengan Glomus aggregatum terhadap serangan penyakit batang berlubang dan pertumbuhan tanaman tembakau. Agrovigor. 5(2):80-93.

Pawana, G., Syekhfani, T. Surtiningsih, W.S. Wahyuni. 2013. Behavior of phosphate solubilization and identification fluorescent pseudomonads Madura indigenous. Asian J. Exp. Biol. Sci. 4(4): 524-531.

Prasad, A.A., S. Babu. 2017. Compatibility of Azospirillum brasilense and Pseudomonas fluorescens in growth promotion of groundnut (Arachis hypogea L.). Annals of the Brazilian Academiy of Science. 89(2): 1027-1040.

Puttaradder, J., H.C. Lakshman. 2017. Effect of am fungi, Azospirillum brasilense and Pseudomonas fluorescence on growth, biomass, nutrient uptake, and yield enhancement in cultivar byadagi kaddi of Capsicum annuum L. International Journal of Pharma and Bio Sciences. 8(1):704-712.

Saber, F.M.A., A.A. Abdelhafes, A. Hasan, E.M. Ramadan. 2015. Characterization of fluorescent pseudomonads isolates and their efficiency on the growth promotion of tomato plant. Annals of Agricultural Science. 60(1):131-140.

Zadeh, P.A., N.S. Rastin, H.A. Rahmani, K. Khavazi, A. Soltani, A.R.S. Nejati, M. Miransari. 2010. Plant growth-promoting activities of fluorescent pseudomonads, isolated from the Iranian soils. Acta Physiologiae Plantarum. 32(2):281-288. DOI: 10.1007/s11738-009-0405-1 